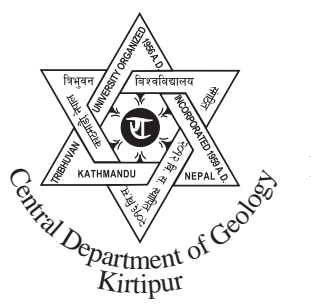

\title{
Morphology and classification of the main stem Bagmati River, Central Nepal
}

\author{
Pramila Shrestha ${ }^{1}$ and $*$ Naresh Kazi Tamrakar 2 \\ ${ }^{1}$ Department of Irrigation, Jawalakhel, Kathmandu, Nepal \\ ${ }^{2}$ Central Department of Geology, Tribhuvan University, Kathmandu, Nepal
}

\begin{abstract}
Rivers are significant geomorphic agents which can carry huge amounts of sediments and water from their catchments to depositional basins. Due course of flow they can bring various hazards such as flooding, inundation of flood plains, erosion of banks and trigger various slope movements. To understand nature and behavior of the Bagmati River, which is a perennial, storm and spring-fed, eight order river of central Nepal, the planiform morphological parameters of this river were analysed and river segments along the main stem stretches were classified into various stream-types, using topographic maps, aerial photographs, and satellite imageries.
\end{abstract}

The Bagmati River is an 8th order perennial river. The Bagmati River basin comprises 39 sub-basins of 4th order and higher. The averages of meander wavelengths $\left(\mathrm{L}_{\mathrm{m}}\right)$, meander belt width $\left(\mathrm{W}_{\mathrm{blt}}\right)$, radius of curvature $\left(\mathrm{R}_{\mathrm{c}}\right)$ and sinuosity $(\mathrm{K})$ of the 7th order main stem Bagmati River are 598.27 m, 164.07 m, 252.35 m and 1.38, respectively. Similarly, the averages of $\mathrm{L}_{\mathrm{m}}, \mathrm{W}_{\mathrm{blt}}, \mathrm{R}_{\mathrm{c}}$, and $\mathrm{K}$ of the 8th order main stem rivers are respectively, 496.77, $126.58 \mathrm{~m}, 286.13 \mathrm{~m}$, and 1.55. All these parameters reflect fluctuating trends of variation along the downstream stretch. However, the portion of the 7th order river shows abrupt increase of $\mathrm{L}_{\mathrm{m}}$ after the Bagmati River crosses the Main Boundary Thrust. The $\mathrm{R}_{\mathrm{c}}$ also indicates slight increase in this region. The sinuosity reflects overall increase from the 7 th to the 8 th order rivers. This increase in sinuosity is attributed to the decrease in slope and competency of the river. There exists a moderate degree of correlation between $\mathrm{K}$ and $\mathrm{W}_{\mathrm{blt}}$ showing that the $\mathrm{W}_{\mathrm{blt}}$ of the Bagmati River tends to increase as the sinuosity increases.

The stream segments of the Bagmati River fall on A-, B-, C-, G- and D-type rivers. All the segments of the Bagmati River, lying within the Kathmandu Valley and having substrate of the fluvio-lacustrine valley-fill sediments, fall on C-type stream because of low entrenchment and high width/depth ratio. Similarly, A-type streams are developed at segments which flow through the Tistung Formation of the granite terrain of the Lesser Himalaya most probably due to entrenched and gorged valley and high slope. Likewise, B- and G-type streams are developed in terrains of the Lesser Himalaya and the Sub-Himalaya. The B-type streams are moderately entrenched with sinuous to meandering and wide channels. The D-type stream segment which is a multi-thread channel is characteristically developed within the terrain of the Sub-Himalaya presumably due to the change in slope caused by thrusting, and greater input of sediments from the Siwaliks in relation to weak and loosely consolidated lithology.

Key words: Stream order, Sinuosity, Meandering River, Bagmati River, Kathmandu Basin, Sub-Himalaya

\section{INTRODUCTION}

Rivers are significant geomorphological agents that exhibit diversity of pattern and behavior (Selby, 1983). The nature and the rate of development of different patterns probably depend on weathering and tectonic

*Corresponding author:

E-mail address: nktam555@gmail.com condition. In tectonically uplifting landscapes, the mass movements and valley floor aggradations are prominent (Marutani et al., 2001). The Nepal Himalaya is geologically young, tectonically active and inherently fragile, thus causing development of different morphological features and patterns of the river. The river patterns thus developed are indicative of dynamism of the river system. 
Determination of the morphological parameters and assignment of the river stretches to a classification scheme is the preliminary task, which is made to understand the river types. These data are applicable to evaluation of river condition and stability. The dynamism of the river is necessary to understand to develop strategies for management of flood plain and control bank erosions. Understanding of river dynamism and its related processes, and river stability condition are very important for watershed management, wetland management, flooding mitigation, reservoir sedimentation management and sustainable development of infrastructures.

Hazard analysis and mapping of the Bagmati River Basin (BRB; Fig. 1) initiated after the disaster of 1993 (DWIDP, 2005). ICIMOD and DPTC carried out preliminary disaster assessment in the BRB and adjacent areas after the extreme events of 1993. DWIDP (2009) prepared hazard maps of the BRB, and identified the

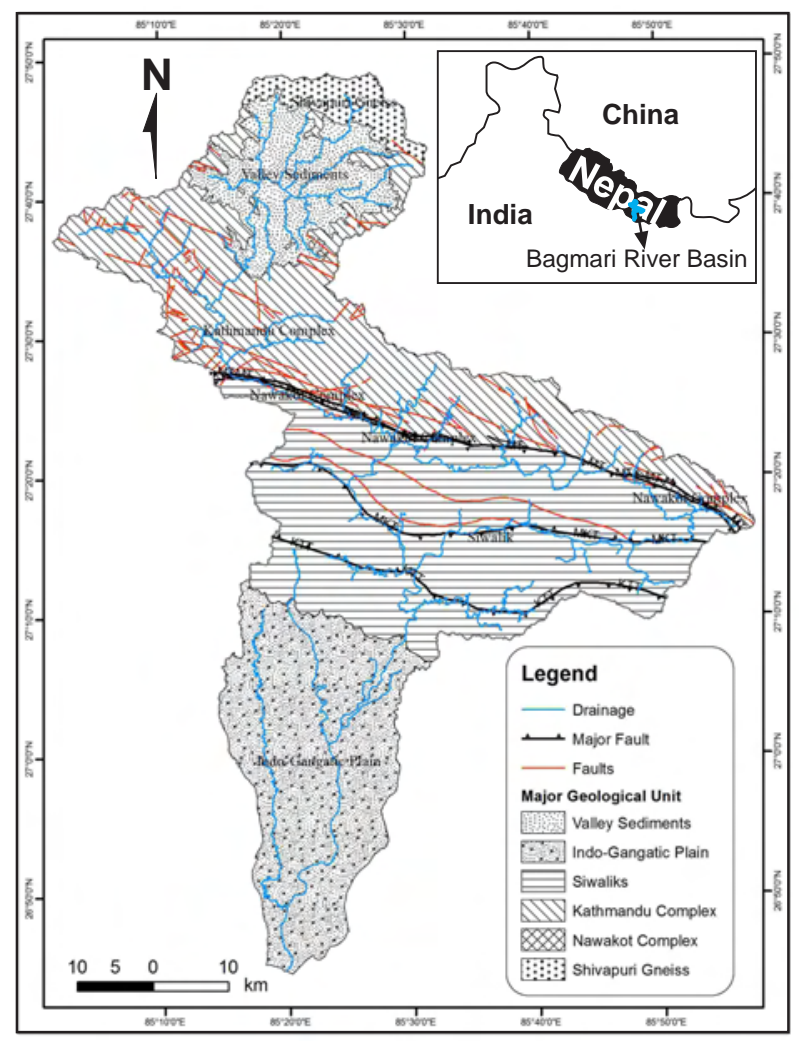

Fig. 1 Location of the study area with Bagmati River Basin showing major geological units and tectonic lines (based on Stöcklin and Bhattarai (1977), Stöckline (1980), Adhikari and Rimal (1996) area prone to landslides, debris flow, flooding inundation and bank cutting. Riverbank erosion and bank failure may produce a significant amount of bed load (Rosgen, 1976). Shrestha and Tamrakar (2007a) evaluated the Manahara River, a tributary of the Bagmati River, in terms of its bank erosion and lateral instability hazard. Shrestha and Tamrakar (2007b) reported relative bank material loss potential of the Manahara River Basin $\left(83 \mathrm{~km}^{2}\right)$ to be 1243 tons per year and average bank recession rate to be $0.33 \mathrm{~m} / \mathrm{yr}$. Bhusal (1998) interpreted that the sediment loss from the Siwaliks is the highest in Nepal and this was about 5000 to 15000 tons $/ \mathrm{km}^{2} / \mathrm{yr}$. The sediment yield from the middle mountains ranges from 3000 to 8000 tons $/ \mathrm{km}^{2} / \mathrm{yr}$. This means about $50 \%$ of the sediment was yielded by the Siwaliks alone. According to Ghimire et al. (2006), large gullies in the headwater catchments of the Siwaliks are the major sediment sources which account for 20 to $60 \%$ of the total erosion in the Siwaliks. The rivers in the Siwalik Range are competent enough to carry significant amount of sediments available in the source (Shrestha et al., 2008). Tamrakar and Shrestha (2008) suggested that rivers originating from the Lesser Himalaya with unstable slope are even more capable to flush out sediment compared to the rivers of the Siwaliks. Thus depending on the terrains, dynamism of rivers may alter as reflected by some changes of various morphological attributes such as slopes, sinuosity, entrenchment ratio, width/depth ratio, etc. This study yields morphological parameters and classifies the main stem Bagmati River.

\section{GEOLOGICAL OUTLINES OF THE BAGMATI RIVER BASIN}

The BRB is characterized from the south to the north by the following geological units (based on Stöcklin and Bhattarai, 1977; Stöcklin, 1980; Adhikari and Rimal, 1996; DWIDP, 2005): (a) Indo-Gangetic Plain, (b) Sub-Himalaya, and (c) Lesser Himalaya (Fig. $1)$.

\section{Indo-Gangatic Plain}

It consists of the Pleistocene to the Recent alluvium of gravel, sand, silt and clay deposited by the rivers originating within the Himalayas or beyond. The average thickness of the sediments is about $1500 \mathrm{~m}$. 
There is a gradation from the coarser to the finer sediment from the northern to the southern parts of the plain (Table 1).

\section{Sub-Himalaya}

The Sub-Himalaya (Siwalik Group) is thrust over the sediments of the Indo-Gangetic Plain along the Main Frontal Thrust (MFT). It is separated from the Lesser Himalaya by the Main Boundary Thrust (MBT). The whole Siwaliks consist of alternating sequences of mudstone, sandstone and conglomerate. Based on grain size and facies assemblages, the Siwaliks are divisible into the Lower, Middle and Upper Siwaliks (Table 1).

Within the Siwalik terrain, there also lies a thrust slice of the Pre-Siwaliks which are characterized by fine- to medium-grained, ripple laminated, pink sandstone and minor green and purple shale (Adhikari and Rimal, 1996 ; DWIDP, 2005). The Siwaliks in the BRB are intersected by two north dipping east-west extending thrusts, viz. Marin Khola Thrust (MKT) and Kamala Tawa Thrust (KTT). The MKT has brought the Lower Siwaliks over the Upper Siwaliks. The KTT extends through the Chiruwa Khola in the western part, crosses the Bagmati River, and extends roughly through the Kyan Khola in the eastern part.

\section{Lesser Himalaya}

The Lesser Himalaya comprises the autochthonous Nawakot Complex and the allochthonous Kathmandu Complex. The Nawakot Complex lies immediately north of the MBT, and consists almost exclusively of low-grade metasedimentary rocks, and is regionally subdivided into the Lower and the Upper Nawakot Groups (Stöcklin, 1980). However, the Lower Nawakot Group is completely absent in the BRB. Among the three units of the Upper Nawakot Group (Table 1), the Benighat Slates is continuous throughout the BRB, but the Malekhu Limestone and the Robang Formation exist only as narrow strips in the eastern part of the BRB.

The Kathmandu complex overlies the Nawakot Complex along the Mahabharat Thrust (MT). The Kathmandu Complex is subdivided into the Precambrian Bhimphedi Group consisting relatively high-grade metamorphic rocks such as garnetiferous schist, biotite schist, marble and quartzite, and the Phulchoki Group of unmetamorphosed to weakly

Table 1: Geological information of the Bagmati River (based on Stocklin, 1980; Gautam and Rösler, 1999)

\begin{tabular}{|c|c|c|c|c|c|}
\hline Terrain & Complex & Group & Formation & Lithology & Age \\
\hline Indo-Gangetic Plain & & & & Gravel, sand, silt and clay & Quaternary \\
\hline \multirow[t]{3}{*}{ Siwalik Group } & & & Upper Siwaliks & Cgl., mst., sst. & Early Pliestocene \\
\hline & & & Middle Siwaliks & Coarse-grained sst., mst. & $\begin{array}{l}\text { Mid Pliocene to } \\
\text { Late Pliocene }\end{array}$ \\
\hline & & & Lower Siwaliks & Fine-grained sst., mst., slst. & $\begin{array}{l}\text { Mid-Miocene to } \\
\text { Early Pliocene }\end{array}$ \\
\hline \multirow[t]{14}{*}{ Lesser Himalaya } & \multirow{11}{*}{$\begin{array}{l}\text { Kathmandu } \\
\text { Complex }\end{array}$} & \multirow{5}{*}{$\begin{array}{l}\text { Phulchoki } \\
\text { Group }\end{array}$} & Godavari Limestone & Limestone & Devonian \\
\hline & & & Chitlang Formation & Slate & Silurian \\
\hline & & & Chandragiri Formation & Limestone & Ordovician \\
\hline & & & Sopyang Formation & Calc. phyllite, qzt. & Cambrian \\
\hline & & & Tistung Formation & Meta-sst., phy, meta-slst., shale & Early Cambrian \\
\hline & & \multirow{6}{*}{$\begin{array}{l}\text { Bhimphedi } \\
\text { Group }\end{array}$} & Markhu Formation & Calc. sch., lst., qzt. & Precambrian \\
\hline & & & Kulekhani Formation & Biotite sch., quartzose schist, qzt. & Precambrian \\
\hline & & & Chisapani Quartzite & White quartzite & Precambrian \\
\hline & & & Kalitar Formation & Biotite schist, quartzite & Precambrian \\
\hline & & & Bhainsedovan Marble & Marble & Precambrian \\
\hline & & & Raduwa Foramtion & Garnetiferous schist & Precambrian \\
\hline & \multirow[t]{3}{*}{$\begin{array}{l}\text { Nawakot } \\
\text { Complex }\end{array}$} & \multirow{3}{*}{$\begin{array}{l}\text { Upper } \\
\text { Nawakot } \\
\text { Group }\end{array}$} & Robang Formation & $\begin{array}{l}\text { Phyllite, serricite } \\
\text { quartzite, basic rocks }\end{array}$ & Post Early Paleozoic \\
\hline & & & Malekhu Limestone & Limestone, dolomite & Post Early Paleozoic \\
\hline & & & Benighat Slate & Slate, phyllite, lst. & Post Early Paleozoic \\
\hline
\end{tabular}

$\mathrm{Cgl} .=$ conglomerate, $\mathrm{sst} .=\mathrm{sandstone}, \mathrm{mst} .=$ mudstone, slst.=siltstone, lst.=limestone, phy. $=$ phyllite, qzt.=quartzite, sch.=schist, calc. $=$ calcareous 
metamorphosed sedimentary rocks such as metasandstone, limestone, shale, slate and phyllite of Early to Middle Paleozoic age (Stocklin, 1980) (Table 1). Besides, the BRB comprises granitic and gneissic rocks in the Kathmandu Complex.

The Lesser Himalaya also comprises PliocenePleistocene basin-fill sediments as: Unconsolidated Sediments (Recent Alluvial Soil, Residual Soil, Colluvial Soil, and Alluvial Fan Deposit) and Consolidated Sediments (Tokha Formation, Gokarna Formation, Chapagaon Formation, Kalimati Formation, Kobgaon Formation and Basal Boulder Beds), in the midland zone. The basin-fill sediments overlie the basement rocks of the Pre-Cambrian to Devonian ages (Stöcklin, 1980; Yoshida and Igarashi, 1986). The lithology of the basement rocks as classified based on DMG (1998) is shown in Table 1.

\section{PHYSIOGRAPHIC SUBDIVISION OF THE BAGMATI RIVER BASIN}

From the south to the north of the BRB there are distinct topographic breaks characterized by various physiographic zones: (a) Terai Plain, (b) Siwaliks (Chure Range) with Dun Valleys, (c) Mahabharat Range and (d) Midlands (Fig. 2).

\section{Terai Plain}

The Terai Plain is the southernmost physiographic unit, and is a depositional landform with floodplains and recent and old river terraces. The altitude of the Terai Plain in the BRB varies from 75 to $150 \mathrm{~m}$. The Terai Plain can be distinguished into three major landforms as Upper Piedmont, Lower Piedmont and Active Alluvial Plain. The Upper Piedmont is produced by coalescing fans adjacent to the Siwaliks.

\section{Siwaliks with Dun Valleys}

The Siwalik Range rises abruptly from the Terai Plain upto an altitude of about $1500 \mathrm{~m}$, and produces the foothills of the Himalayas. The Siwaliks generally have a rugged topography with deeply dissected gullies and steep slopes formed by questas. The Siwaliks contain wide valleys of the Bagmati River and the Marin Khola. Low to high terraces adjacent to the river, alluvial fans, badlands and thin sandy soil covers are features found in this zone.

\section{Mahabharat Range}

The Mahabharat Range rises abruptly from the Siwalik Hills, and approaches the maximum altitude of about $3000 \mathrm{~m}$. The Mahabharat Range exhibits a youthfull topography often characterized by mountains, deep gorges and rugged landforms. The entire Mahabharat Range in the BRB, except for its southern edge that is made up of the rocks of the Nawakot Complex, is composed of the rocks of the Kathmandu Complex.

\section{Midlands}

The Midlands locate north of the Mahabhrat Range and is characterized by lowering of the altitude up to $1000 \mathrm{~m}$. The topography is mild with lower hills and wider valleys with recent and old terraces. The Kathmandu Valley is located in this zone and is characterized by dendritic, sub parallel and centripetal drainage systems. The entire Midlands and the BRB are composed of the rocks of the Kathmandu Complex.

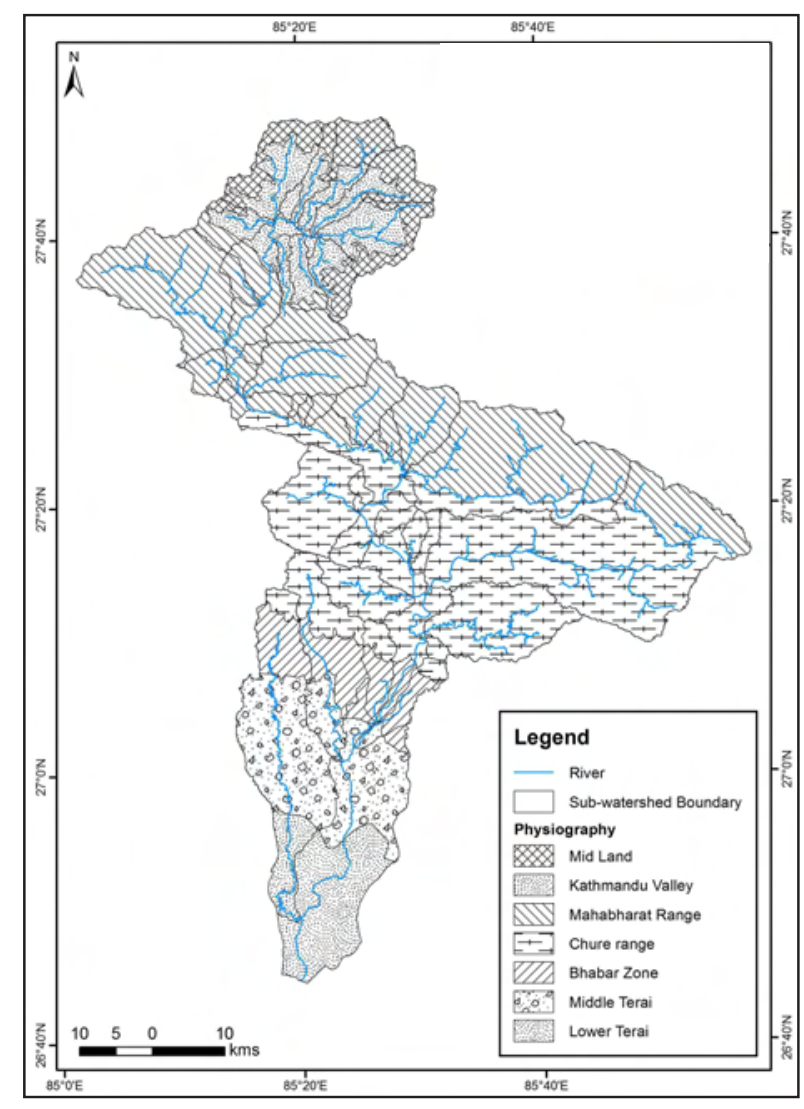

Fig. 2 Physiography of the Bagmati River Basin (based on Hagen's (1956) subdivision) 


\section{MORPHOLOGICAL CRITERIA FOR LEVEL I CLASSIFICATION}

The stream system variables were utilized in the level I hierarchical inventory. This broad level classification allowed for rapid initial morphological delineation of stream types and organization of river information and amount of river types, A through G, to be determined within a basin. It also assisted in setting for condition of more detail assessment. The morphological context of the planform, profile and shape of the river provided: an indication of the general channel slope, shape (W/D ratio), channel pattern (single versus multi-thread channel), and delineation of general degree of confinement or lateral containment of the river. Level I classification was based on geomorphic features which can be interpreted from aerial photograph, satellite images, topographic maps, etc. The satellite imageries from Google Earth is very helpful for broad level stream classification as it

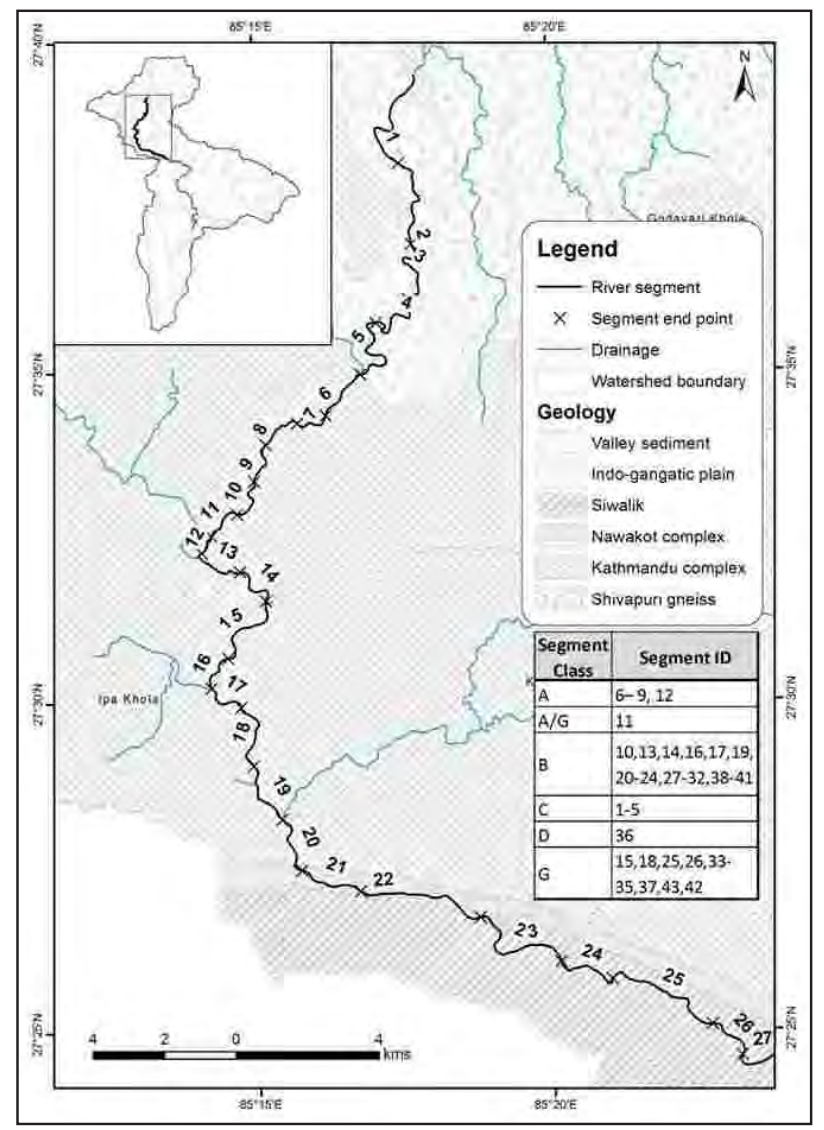

(a) provides detail features of terrains up to about $2 \mathrm{~m}$ depth. Then, the information acquired from the satellite imagery and topographic maps was then analysed into the ArcGIS environment using spatial analysis tools combined with geo-processing and geostatistical tools. For this classification, the Bagmati River up to the Siwaliks was considered. Then the river corridor was fragmented into 43 segments ( 38 segments beyond and 5 segments within the Kathmandu Valley) considering one complete meandering cycle as one segment for single thread channel and the all the multithread channel was grouped into one segment (Fig. 3 $a, b)$. The morphologic parameters required for broad level classification was measured and calculated for each segments.

\section{Valley types}

Delineation of the pertinent valley types provides a logical stratification with which to identify the

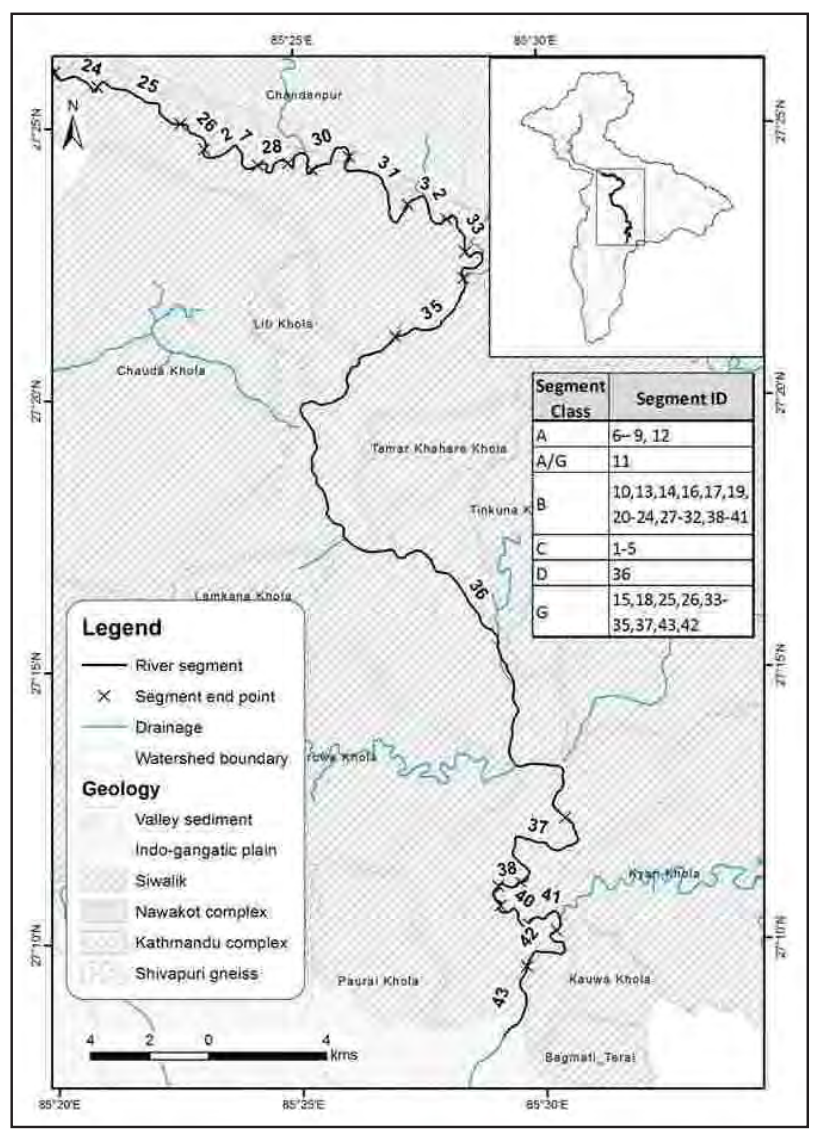

(b)

Fig. 3 Location of the river segment ID and distribution of stream types along the main stem Bagmati River: (a) Upstream portion and (b) Downstream portion continued 
potential number of stream types within a broad area. The types of river valleys present at the segments along the Bagmati River course were delineated from topographic map, DEM and satellite imageries.

\section{Stream ordering}

A river basin consists of its several branches (segments) having different positions in the basin area and they have their own morphometric characteristics and, therefore it becomes necessary to locate the relative position of a segment in the basin, so that the hierarchical organization of stream can be visualized (Leopold, Wolman and Miller, 1969). In this study, the drainage order was determined using the method proposed by Strahler (1969). It may be mentioned that the hierarchical order increases only when two stream segments of equal order meet and form a junction. The stream order was computed from the digital layers acquired from the Department of Survey and by using ArcGIS software.

\section{Plan-view morphology}

Plan views of river patterns are grouped as: relatively straight ('A' stream type), low sinuosity ('B' stream type), meandering (' $\mathrm{C}$ ' and ' $\mathrm{F}$ ' stream types), torturously meandering ('E' stream types), and the complex stream patterns such as braided ('D' stream types) and anastomosed ('DA' stream type).

The plan-view morphology is well attributed by various parameters: meander wavelength $\left(\mathrm{L}_{\mathrm{m}}\right)$, meander belt width $\left(\mathrm{W}_{\mathrm{blt}}\right)$, radius of curvature $\left(\mathrm{R}_{\mathrm{c}}\right)$ and sinuosity $(\mathrm{K})$. Meander wavelength $\left(\mathrm{L}_{\mathrm{m}}\right)$ of the river is the distance between two successive crests or two successive trough of the curved channel (Fig. 4). $\mathrm{W}_{\text {blt }}$ is a straight line between the crest of the bend to the

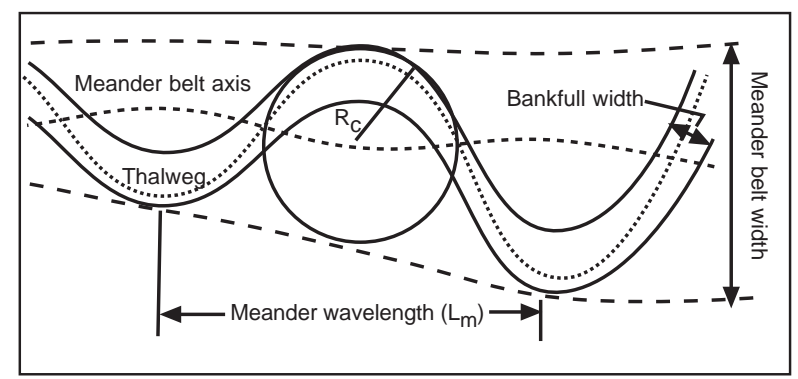

Fig. 4 Planform parameters of the river channel crest of the next bend lying downstream, or is the distance between lines defining the confinement of the lateral boundaries of the channel.

$R_{c}$ is the radius of a circle drown through the apex of the bend and the two crossover midpoint of river, and is defined as the curved surface formed by the meandering stream channel. It is calculated by using the formula as:

$$
\mathrm{R}_{\mathrm{c}}=\left(\mathrm{C}^{2} / 8 \mathrm{M}\right)+(\mathrm{M} / 2)
$$

Where, $\mathrm{C}=$ Chord length between inflection points, and $\mathrm{M}=$ Middle ordinate distance between the curve crest and the chord. The radius of curvature relationship is used to evaluate channel resistance to erosion and a meander migration rate.

Channel sinuosity, which is the ratio of stream channel length to down-valley distance, was measured from satellite imageries, aerial photographs and topographic maps. With the exception of the large rivers, if sinuosity were computed for smaller stream systems using only topographic maps, significant underestimations would have been occurred in the process of map configuration. The channel sinuosity that is a primary indicator of types of stream is also an indication of how stream channel slope is adjusted to that of the valley slope. When it is measured accurately from aerial photographs, channel sinuosity may also be used to estimate channel slope (valley slope/sinuosity). All the planform parameters for the Bagmati River were measured and obtained from topographic map of 1:25,000 (scale) and the satellite imagery from Google Earth. The obtained values of the meander width ratio of different segments of the river are shown in Table 2.

\section{Cross-section morphology}

The broad level inventory was also based on interpretation of channel cross-section shapes that would distinguish narrow and deep streams from wide and shallow stream types. Channel systems characteristics which are important for the Level I scheme are: (a) degree of channel incision within the parent valley, (b) the location and extent of floodplains, (c) the occurrence and position of terraces, (d) the prevalence of colluvial slopes, (e) the presence of 
Table 2: Morphological details of different segments of the Bagmati River

\begin{tabular}{|c|c|c|c|c|c|c|c|}
\hline \multirow{2}{*}{$\begin{array}{r}\text { Segmer } \\
\text { ID } \\
1\end{array}$} & \multirow{2}{*}{$\begin{array}{c}\text { t Strear } \\
\text { order }\end{array}$} & \multirow{2}{*}{$\begin{array}{l}\text { Segment } \\
\text { length, km }\end{array}$} & \multirow{2}{*}{$\frac{\left(\mathrm{L}_{\mathrm{m}}\right), \mathrm{m}}{1115.80}$} & \multirow{2}{*}{$\begin{array}{c}\mathrm{W}_{\text {blt }}, \mathrm{m} \\
336.34\end{array}$} & \multirow{2}{*}{$\begin{array}{c}\mathrm{R}_{\mathrm{c}}, \mathrm{m} \\
473.57\end{array}$} & \multicolumn{2}{|c|}{$\begin{array}{l}\text { Sinuosity } \\
(\mathrm{K})^{*}\end{array}$} \\
\hline & & & & & & 1.57 & $\mathrm{MC}$ \\
\hline 2 & 7th & 2.76 & 803.68 & 175.49 & 301.51 & 1.21 & SC \\
\hline 3 & 7th & 2.36 & 595.14 & 219.73 & 256.98 & 1.53 & MC \\
\hline 4 & 7th & 2.21 & 1115.80 & 336.34 & 176.85 & 1.98 & $\mathrm{MC}$ \\
\hline 5 & 7th & 2.94 & 527.67 & 310.22 & 180.97 & 1.9 & MC \\
\hline 6 & 7th & 1.67 & 594.90 & 77.61 & 290.04 & 1.07 & SC \\
\hline 7 & 7th & 1.05 & 556.29 & 148.03 & 174.36 & 1.26 & SC \\
\hline 8 & 7th & & 381 & & & 1.08 & SC \\
\hline 9 & 7th & 1. & & & & 1.15 & SC \\
\hline 10 & 7th & & 559 & 190.12 & 211 & 1.28 & SC \\
\hline 11 & 7th & & 393. & & & 1.18 & SC \\
\hline 12 & 7th & 0.55 & 312.04 & & & 1.04 & SC \\
\hline 13 & 7th & 1.56 & 298.27 & 4.74 & 331.11 & 1.31 & $\mathrm{SC}$ \\
\hline 14 & 7th & 1.4 & 627.08 & 266.17 & & 1.36 & SC \\
\hline 15 & 7th & & & 1.75 & & 1.26 & SC \\
\hline 16 & 7th & & & 1.44 & & 1.19 & SC \\
\hline 17 & 7th & & & & & 1.24 & SC \\
\hline 18 & 7th & & & & 221.19 & 1.24 & SC \\
\hline 19 & 7th & 1. & 4.25 & & & 1.13 & SC \\
\hline 20 & 7th & & 51 & 174.25 & 199.86 & 1.68 & MC \\
\hline 21 & 7th & 1.84 & & & 363 & 1.06 & SC \\
\hline 22 & 7th & 67 & 945.60 & 14.60 & 433 & 1.07 & SC \\
\hline 23 & 7th & 3.46 & 469.80 & 85.88 & 479.97 & 1.35 & SC \\
\hline 24 & 7th & 1.91 & 522.77 & 127.70 & 274.42 & 1.25 & SC \\
\hline 25 & 7th & & 6 & 20 & 368 & 1.14 & SC \\
\hline 26 & 7th & & & 3.82 & 223.82 & 1.18 & $\mathrm{SC}$ \\
\hline 27 & 7th & & 16 & 2.96 & 193 & 1.48 & SC \\
\hline 28 & 7th & & & & & 1.56 & MC \\
\hline 29 & 7th & & & & & 2.27 & $\mathrm{MC}$ \\
\hline 30 & 7th & & 6 & 0.33 & 193 & 1.44 & SC \\
\hline 31 & 7th & & 70 & 177.60 & 255 & 1.64 & MC \\
\hline 32 & 7th & 2.1 & & 33 & 168 & 1.51 & $\mathrm{MC}$ \\
\hline 33 & 7th & & & & & 1.25 & SC \\
\hline 34 & 7th & & & & 139 & 2.31 & MC \\
\hline 35 & 7th & & 634.06 & 88.10 & 409.46 & 1.16 & SC \\
\hline 36 & 7th & & Mul & thread c & nannel & & \\
\hline Mea & & 2.09 & 598.27 & 164.07 & 252.35 & 1.38 & \\
\hline Standar & d deviat & ion 0.88 & 181.75 & 81.01 & 91.14 & 0.32 & \\
\hline 37 & 8th & 5.24 & 562.25 & 155.85 & 238.6 & 1.97 & MC \\
\hline 38 & 8th & & 419 & 105 & 149.6 & 1.14 & SC \\
\hline 39 & 8th & 0.8 & 334 & 110 & 121 & 1.3 & SC \\
\hline 40 & 8th & & & & 128.06 & 1.49 & SC \\
\hline 41 & 8th & & & & 208.46 & 1.94 & $\mathrm{MC}$ \\
\hline 42 & 8th & & & & 193.52 & 1.82 & MC \\
\hline 43 & 8th & 2.75 & & 119.50 & 456.9 & 1.19 & $\mathrm{SC}$ \\
\hline Mea & & 2.31 & 496.77 & 126.58 & 213.86 & 1.55 & \\
\hline Standar & . & tion 1.40 & 144.91 & 36.61 & 106.96 & 0.33 & \\
\hline
\end{tabular}

"Sinuosity: $\mathrm{MC}=$ Meandering Channel $(\mathrm{K}>1.50), \mathrm{SC}=$ Sinous Channel $(\mathrm{K}=1.05$ to 1.50$)$ based on Leopold and Wolman (1957)

structural control features, (f) the degree of channel confinement and entrenchment, and $(\mathrm{g})$ the overall valley versus channel macro-dimensions.
The channel cross-sectional shape of all the segments of the Bagmati River was distinguished from the satellite imagery from Google Earth which had sufficient fine resolution to $2 \mathrm{~m}$ for this study.

\section{Bed features}

The longitudinal profile, which can be generally inferred from topographic maps, changes with channel sinuosity in the down-valley direction, and serves as the basis for delineating stream reaches into general slope categories that reflect morphology of the channel profile. Bed features are also related to channel slope, and both parameters are integral to delineation of stream types.

\section{MORPHOLOGY AND CLASSIFICATION OF THE BAGMATI RIVER}

The results of analyses of all the morphological parameters and the resulting classification of the Bagmati River are presented in Tables 2 and 3.

\section{Stream order}

The main stem Bagmati River originates from the eastern hill, Nagarkot in Kathmandu Valley within the catchment of the Hanumante River. The latter is a 6th order river that stretches for $18.30 \mathrm{~km}$. It confluences with another 6th order Godawori River (channel length $16.08 \mathrm{~km}$ ) near Balkot and forms a 7th order main stem Bagmati River. The Bagmati River that flows in the Kathmandu Valley stretches for about $51 \mathrm{~km}$ and comprises catchment area of about 678 square $\mathrm{km}$. The 7th order main stem Bagmati River further stretches towards the south for about $50 \mathrm{~km}$ beyond the Kathmandu valley, through the Mahabharat Range and becomes 8th order stretch in the Sub-Himalayan zone where it further extends for about $104.18 \mathrm{~km}$ within the territory of Nepal. The total catchment area of the Bagmati River Basin approaches 3761 square km.

As soon as the Bagmati River drains out from the Kathmandu Valley, it starts incising the rocks of the Lesser Himalaya and flows through the Siwaliks receiving flows from several lower order drainages along its stretch. But at Sikere Dobhan, which lies in the Middle Siwalik zone, the seventh order Kokhajor Khola confluences with the Bagmati River that then 
Table 3: Result of broad level classification of the Bagmati River

\begin{tabular}{|c|c|c|c|c|c|}
\hline $\begin{array}{l}\text { Segment } \\
\text { ID }\end{array}$ & $\begin{array}{c}\text { Stream } \\
\text { order }\end{array}$ & $\begin{array}{l}* \text { Entrenchment } \\
\text { ratio }\end{array}$ & $\begin{array}{c}\text { Sinuosity } \\
(\mathrm{K})\end{array}$ & Geological Formation & $\begin{array}{c}\text { Stream } \\
\text { type }\end{array}$ \\
\hline 1 & 7th & ME to SE & 1.57 & Fluvio-lacustrine valley-fill sediment & $\mathrm{C}$ \\
\hline 2 & 7th & ME to SE & 1.21 & Fluvio-lacustrine valley-fill sediment & $\mathrm{C}$ \\
\hline 3 & 7th & ME to SE & 1.53 & Fluvio-lacustrine valley-fill sediment & $\mathrm{C}$ \\
\hline 4 & 7th & ME to SE & 1.98 & Fluvio-lacustrine valley-fill sediment & $\mathrm{C}$ \\
\hline 5 & 7th & ME to SE & 1.90 & Fluvio-lacustrine valley-fill sediment & $\mathrm{C}$ \\
\hline 6 & 7th & E & 1.07 & **Lesser Himalaya (LH): Tistung Formation & A \\
\hline 7 & 7th & $\mathrm{E}$ & 1.26 & (LH): Tistung Formation & A \\
\hline 8 & 7th & $\mathrm{E}$ & 1.08 & (LH): Tistung Formation & A \\
\hline 9 & 7 th & E & 1.15 & (LH): Tistung Formation & A \\
\hline 10 & 7 th & ME & 1.28 & (LH): Tistung and Markhu Formations & B \\
\hline 11 & 7th & $\mathrm{E}$ & 1.18 & (LH): Granite & A \\
\hline 12 & 7 th & E & 1.04 & (LH): Granite & A \\
\hline 13 & 7 th & $\mathrm{ME}$ & 1.31 & (LH): Granite & B \\
\hline 14 & 7th & ME & 1.36 & (LH): Granite + Quaternary Terrace Deposit (QTD) & B \\
\hline 15 & 7th & $\mathrm{E}$ & 1.26 & (LH): Chisapani and Kulekhani Formations & $\mathrm{G}$ \\
\hline 16 & 7th & ME & 1.19 & (LH): Kulekhani and Markhu Formations & B \\
\hline 17 & 7th & ME & 1.24 & (LH): Kulekhani and Markhu Formations & B \\
\hline 18 & 7th & $\mathrm{E}$ & 1.24 & (LH): Kulekhani, Chisapani and Markhu Formations & $\mathrm{G}$ \\
\hline 19 & 7th & $\mathrm{ME}$ & 1.13 & (LH): Kalitar, Bhainsedovan, Raduwa and Benighat Formations & B \\
\hline 20 & 7th & $\mathrm{E} / \mathrm{ME}$ & 1.68 & LH: Benighat Slate, and Middle Siwaliks & B \\
\hline 21 & 7th & ME & 1.06 & Middle Siwaliks & B \\
\hline 22 & 7th & ME & 1.07 & Upper and Middle Siwaliks & $\mathrm{B}$ \\
\hline 23 & 7th & $\mathrm{ME} / \mathrm{SE}$ & 1.35 & Upper and Middle Siwaliks & B \\
\hline 24 & 7th & ME & 1.25 & Upper and Middle Siwaliks & B \\
\hline 25 & 7th & ME & 1.14 & Upper and Middle Siwaliks & $\mathrm{G}$ \\
\hline 26 & 7th & $\mathrm{ME}$ & 1.18 & Upper and Middle Siwaliks & $\mathrm{G}$ \\
\hline 27 & 7th & $\mathrm{E} / \mathrm{ME}$ & 1.48 & Upper and Middle Siwaliks & $\mathrm{B}$ \\
\hline 28 & 7th & $\mathrm{E} / \mathrm{ME}$ & 1.56 & Upper and Middle Siwaliks & B \\
\hline 29 & 7th & $\mathrm{E} / \mathrm{ME}$ & 2.27 & Upper and Middle Siwaliks + (LH): Benighat Slate & B \\
\hline 30 & 7th & $\mathrm{E} / \mathrm{ME}$ & 1.44 & (LH): Benighat Slate, and Middle Siwaliks + QTD & B \\
\hline 31 & 7th & $\mathrm{E} / \mathrm{ME}$ & 1.64 & Middle Siwaliks & B \\
\hline 32 & 7th & $\mathrm{E} / \mathrm{ME}$ & 1.51 & Middle Siwaliks & B \\
\hline 33 & 7th & $\mathrm{E} / \mathrm{ME}$ & 1.25 & Middle Siwaliks & G \\
\hline 34 & 7th & $\mathrm{E}$ & 2.31 & Middle, Lower and Pre-Siwaliks & G \\
\hline 35 & 7th & E & 1.16 & Middle Siwaliks + QTD & G \\
\hline 36 & 7th & & & Pre-, Lower, Middle and Upper Siwaliks & $\mathrm{D}$ \\
\hline 37 & 8th & SE & 1.97 & Middle Siwaliks & G \\
\hline 38 & 8th & $\mathrm{ME}$ & 1.14 & Middle Siwaliks & B \\
\hline 39 & 8th & $\mathrm{E} / \mathrm{ME}$ & 1.3 & Middle Siwaliks & B \\
\hline 40 & 8th & $\mathrm{ME}$ & 1.49 & Middle Siwaliks & B \\
\hline 41 & 8th & $\mathrm{ME}$ & 1.94 & Middle Siwaliks & B \\
\hline 42 & 8th & $\mathrm{E} / \mathrm{ME}$ & 1.82 & Middle Siwaliks & B \\
\hline 43 & 8th & $\mathrm{E}$ & 1.19 & Lower Siwaliks & G \\
\hline
\end{tabular}

*Entrenchment ratio: $\mathrm{E}=$ Entrenched, $\mathrm{SE}=$ Slightly entrenched, $\mathrm{ME}=$ Moderately entrenched ** $\mathrm{LH}=$ Lesser Himalaya

becomes the 8th order main stem Bagmati River. The River then follows the course towards the south through the rest of the Siwaliks and the Indo-Gangetic Plain.

The major tributaries contributing to the main stem Bagmati River and their highest stream orders and lengths are listed in Table 4. There are altogether thirtynine sub-basins in the Bagmati River Basin. There are one 8th order, two 7 th order, twelve 6th order, sixteen 5 th order, seven 4 th order, and one 2 nd order sub- basins. The length of the 8 th order stream alone is $104.18 \mathrm{~km}$.

\section{Meander wavelength}

Meander wavelength shows a fluctuating and slightly diminishing trend of variation from the upstream segments to the downstream segments of the Bagmati River. The average $\mathrm{L}_{\mathrm{m}}$ of the seventh order and eighth order river segments are respectively $598.27 \mathrm{~m}$ 
Table 4: Stream order, length, total number of sub-basin and physiography of the Bagmati River Basin

\begin{tabular}{|c|c|c|c|c|}
\hline $\begin{array}{l}\text { Stream } \\
\text { order }\end{array}$ & Sub-basin name & $\begin{array}{l}\text { Stream } \\
\text { length, km }\end{array}$ & $\begin{array}{l}\text { Total } \\
\text { number } \\
\text { of basin }\end{array}$ & $\begin{array}{l}\text { Physiog- } \\
\text { raphy }\end{array}$ \\
\hline 8 th & Main stem Bagmati River & 104.18 & 1 & $\begin{array}{l}\text { MZ, MR, S } \\
\text { TP }\end{array}$ \\
\hline \multirow[t]{2}{*}{7 th } & Marin Khola & 51.94 & & MR and $S$ \\
\hline & Kokhajor Khola & 22.89 & 2 & MR and $\mathrm{S}$ \\
\hline \multirow[t]{12}{*}{ 6th } & Bagmati River & 20.82 & & $\mathrm{MZ}$ \\
\hline & Hanumante River & 10.24 & & $\mathrm{MZ}$ \\
\hline & Bishnumati River & 6.07 & & $\mathrm{MZ}$ \\
\hline & Godvari River & 3.43 & & $\mathrm{MZ}$ \\
\hline & Balkhu Khola & 6.64 & & $\mathrm{MZ}$ \\
\hline & Kulekhani Khola & 30.04 & & MR \\
\hline & Ipa Khola & 1.88 & & MR \\
\hline & Khani Khola & 8.14 & & MR \\
\hline & Khani Khola 1 & 5.06 & & MR \\
\hline & Kyan Khola & 28.72 & & MR \\
\hline & Chauda Khola & 7.00 & & $\mathrm{~S}$ \\
\hline & Chiruwa Khola & 13.30 & 12 & S \\
\hline \multirow[t]{16}{*}{5 th } & Manahara River & 21.31 & & $\mathrm{MZ}$ \\
\hline & Dhobi Khola & 12.44 & & $\mathrm{MZ}$ \\
\hline & Nakhu Khola & 14.32 & & $\mathrm{MZ}$ \\
\hline & Kodku Khola & 10.68 & & $\mathrm{MZ}$ \\
\hline & Chaimale Khola & 7.39 & & MR \\
\hline & Chandanpur Khola & 13.43 & & MR \\
\hline & Khor Bhanjyang Khola & 2.49 & & MR \\
\hline & Paurai Khola & 7.73 & & MR \\
\hline & Tinkuna Khola & 5.20 & & MR \\
\hline & Chandi Khola & 37.63 & & $\mathrm{TP}$ \\
\hline & Jhajh Nadi & 74.38 & & $\mathrm{TP}$ \\
\hline & Lamkane Khola & 1.98 & & $\mathrm{~S}$ \\
\hline & Budhi Bagmati Bhangalo & 12.72 & & $\mathrm{~S}$ \\
\hline & Shrighari Khola & 0.18 & & $\mathrm{~S}$ \\
\hline & Mahadev Khola & 0.69 & & $\mathrm{~S}$ \\
\hline & Akasedanda Khola & 0.97 & 16 & $\mathrm{~S}$ \\
\hline \multirow[t]{7}{*}{ 4th } & Sokan Khola & 10.29 & & $\mathrm{~S}$ \\
\hline & Tamar Khahare Khola & 7.51 & & $\mathrm{~S}$ \\
\hline & Deuta Khola & 5.49 & & $\mathrm{~S}$ \\
\hline & Subhane Khola & 3.33 & & $\mathrm{~S}$ \\
\hline & Bhalu Khola & 3.10 & & $\mathrm{~S}$ \\
\hline & Liti Khola & 4.63 & & $\mathrm{~S}$ \\
\hline & Kauwa Khola & 3.49 & 7 & $\mathrm{~S}$ \\
\hline 2 nd & Tukucha Khola & 5.27 & 1 & $\mathrm{MZ}$ \\
\hline
\end{tabular}

MZ=Midland Zone; MR= Mahabharat Range; $S=$ Siwaliks; TP=Terai Plain

(Standard deviation $(\mathrm{SD})=181.75 \mathrm{~m})$ and 496.77 $(\mathrm{SD}=141.91 \mathrm{~m})$. There seems to be weak relationship between geological terrains and the meander wavelength. However, it is true that the portion of the seventh order river flowing over the substrate of the fluviolacustrine valley-fill sediment in the Kathmandu Valley possess higher meandering wavelength (the highest being $1115.80 \mathrm{~m}$ at segment IDs 1 and 4), and $\mathrm{L}_{\mathrm{m}}$ suddenly increases after the Bagmati River crosses the MBT (Fig. 5a).

\section{Meander belt width}

The meandering belt width (Wblt) of the 7th order main stem river varies from 379.38 to $42.41 \mathrm{~m}$. For the 8th order river it ranges from 174.95 to $60.01 \mathrm{~m}$. Here, the highest value indicates the highest magnitude of river wandering and lowest value indicates lowest magnitude of river wandering. The averages of the $\mathrm{W}_{\mathrm{blt}}$ for 7 th and 8 th order main stem rivers are respectively, $164.07 \mathrm{~m}(\mathrm{SD}=181.75 \mathrm{~m})$ and $126.58 \mathrm{~m}$ $(\mathrm{SD}=36.61 \mathrm{~m})$. The meandering belt width shows a fluctuating trend along the stream (Fig. 5a).

\section{Radius of curvature}

The radius of curvature $\left(\mathrm{R}_{\mathrm{c}}\right)$ of the seventh order main stem river varies from 479.97 to $139 \mathrm{~m}$ and that for the eight order river from 456.90 to $121.86 \mathrm{~m}$. The averages for the 7 th and the 8 th order rivers are 252.35 $\mathrm{m}(\mathrm{SD}=91.14 \mathrm{~m})$ and $286.13 \mathrm{~m}(\mathrm{SD}=36.61 \mathrm{~m})$, respectively. The variation trend of the Rc indicates a fluctuating trend (Fig. 5a). However, slightly increasing values can be observed between the terrains of the Mahabharat Range and the Siwalik Range.

\section{Sinuosity}

Sinuosity refers to deviation of actual channel path from expected theoretical (straight) path. River sinuosity indicates how a river has adjusted its slope to that of its valley. The degree of sinuosity also related to channel dimensions, sediment load, stream flow, and the bed and bank materials (Rosgen, 1996). Leopold and Wolman (1957) divided river channels basically into 3 types on the basis of sinuosity index, as straight channel $(K<1.05)$, sinuous channel $(K=1.05$ to 1.5$)$, and meandering channel $(K>1.5)$.

The studied segments of the main steam Bagmati River have varying sinuosity showing a fluctuating trend though it shows overall increase (Fig. 5b). Out of 43 segments, 29 are sinuous channels and 13 are meandering channels. Considering the 7th order stream, about $71 \%$ are sinuous and $29 \%$ are meandering channel segments. In 8th order stream, about $57 \%$ are sinuous and $43 \%$ are meandering channels. The average sinuosity of the seventh order main stem Bagmati River is $1.38(\mathrm{SD}=0.32)$. Similarly, the average sinuosity of the eight order segment is 1.55 ( $\mathrm{SD}=0.33$ ). The eighth order Bagmati River is more sinuous than the seventh 

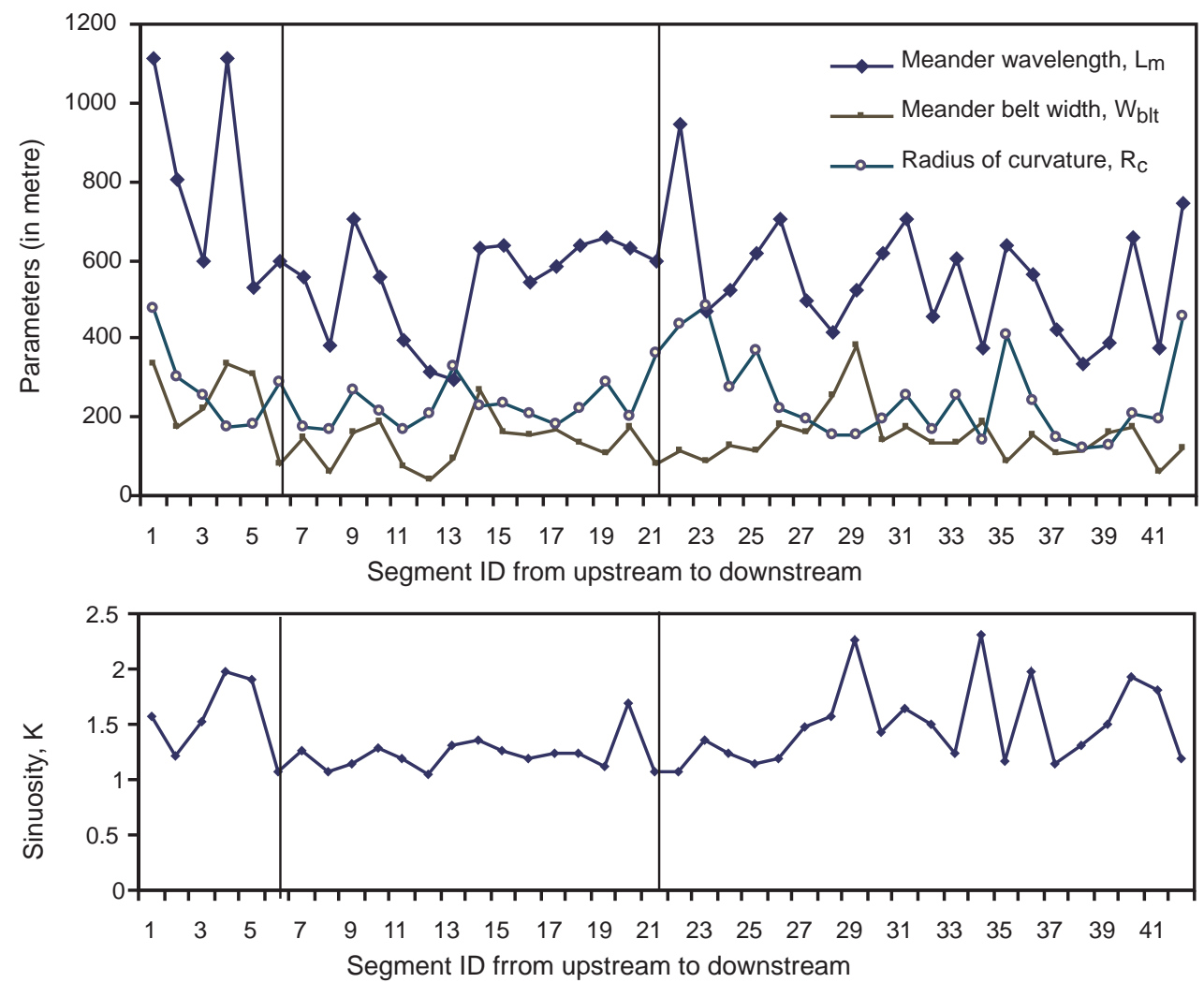

Fig. 5 Downstream variation of planform parameters: (a) Fluctuating trends of meander wavelength, meander belt width and radius of curvature, and (b) Slightly increasing trend of sinuosity though it has a fluctuating pattern.

order segment. This increase in sinuosity is attributed to the decrease in slope and competency of the river.

\section{RELATIONSHIPS AMONG MORPHOLOGICAL PARAMETERS}

The planform parameters when correlated and regressed themselves using bivariate analysis (Fig. 6), have yielded moderate degree of correlation to no correlation. The sinuosity indicates positive and extremely weak degree of correlation with meander wavelength (Fig. 6a), but moderate degree of correlation with meander belt width (Fig. 6b). There are also positive and moderate degree of relationships between meander wavelength and meander belt width (Fig. 6c), and between meander wavelength and radius of curvature (Fig. 6d). The relationships such as $\mathrm{K}$ versus $\mathrm{Rc}$ and Wblt versus Rc are very weak and negative (Figs. 6e and f). Therefore, among the relationships, the one of sinuosity versus meander belt width is somehow satisfactory, and suggests that when sinuosity increases meander belt width of the Bagmati River also tends to increase.

\section{LEVEL I CLASSIFICATION}

The stream segments of the Bagmati River fall on A, B, C, G and D classes. Here, all the segments of the Bagmati River, lying within the Kathmandu Valley and having substrate of the fluvio-lacustrine valleyfill sediments, fall on C-type stream. Similarly, A-type streams are developed at segments which flow through the Tistung Formation and granite terrain of the Lesser Himalaya. Likewise, B- and G-types streams are developed in terrains of the Lesser Himalaya and the Sub-Himalaya. The D-type stream segment is characteristically developed within the terrain of the Sub-Himalaya (Fig. 3 a, b).

The C-type streams are meandering with width channels compared to the depth and are less entrenched compared to A-, B-, and G-types. The B-type stream segments which are more frequent compared to the other types of stream, possess moderate entrenchment, wide channels compared to depth and are sinuous to meandered channels. The A-type streams are localized in the terrain composing metasandstones and granite of the Lesser Himalayas, and are narrow channels with 

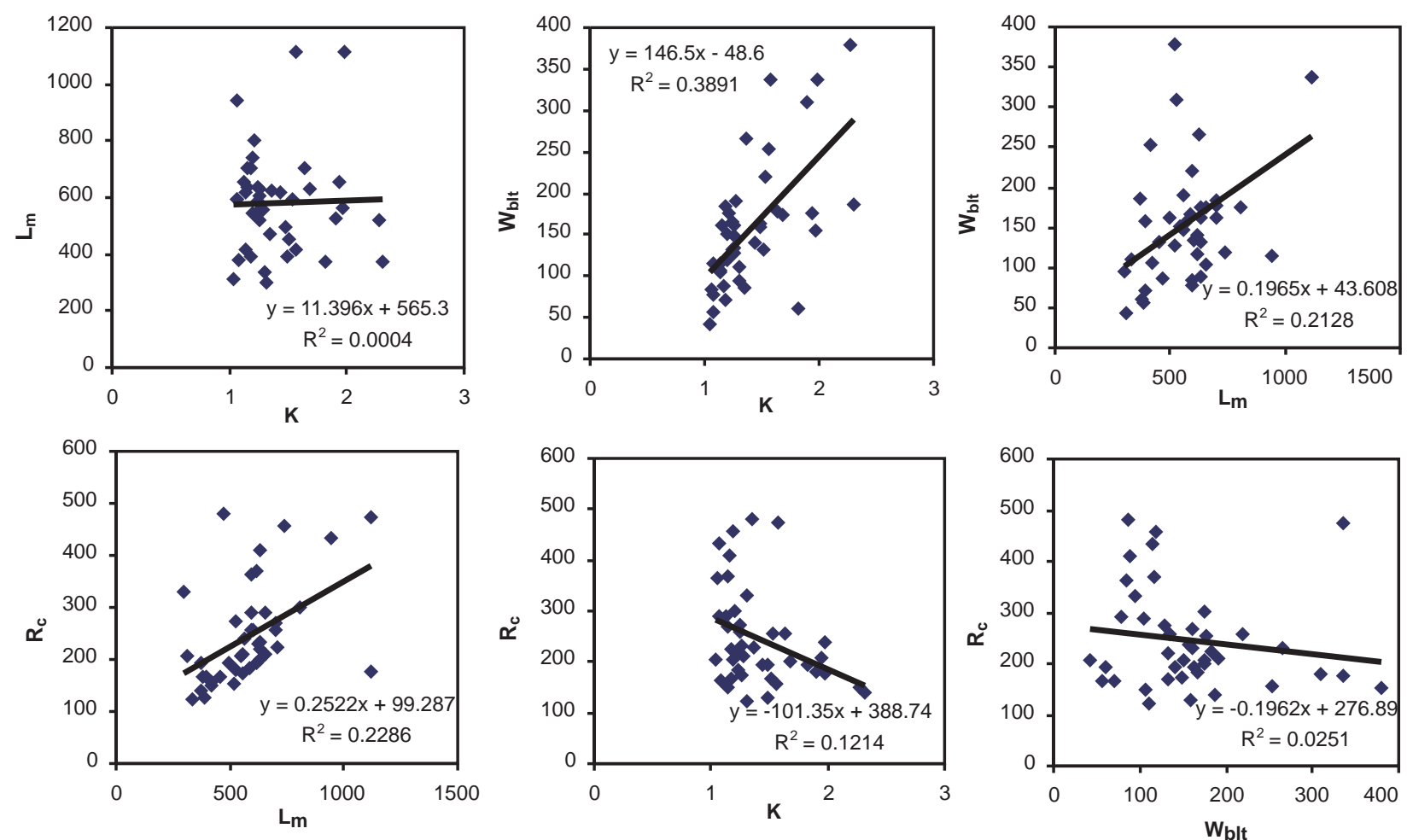

Fig. 6 Relationships between various morphological parameters: (a) $\mathrm{K}$ versus $\mathrm{L}_{\mathrm{m}}$, (b) $\mathrm{K}$ versus $\mathrm{W}_{\text {blt }}$, (c) $\mathrm{L}_{\mathrm{m}}$ versus $\mathrm{W}_{\text {blt }}$, (d) $\mathrm{L}_{\mathrm{m}}$ versus $R_{c}$, (e) $K$ versus $R_{c}$, and (f) $W_{\text {blt }}$ versus $R_{c}$. The relationships in (b), (c), and (d) are moderately positive, in (a) is almost no correlation, and in (e) and (f) are weakly negative.

greater degree of entrenchment, low width of the channel compared to the depth, low degree of sinuosity and with steeper slope compared to the rest of the stream types. The multi-thread channel, D-type stream is found in the Siwalik region, where it is influenced by large input of sediments from the south-north flowing tributaries from the relatively young loosely consolidated conglomerates of the Upper Siwaliks, and thrusting.

\section{CONCLUSIONS}

The drainage order analysis of the Bagmati River results that, the main stem Bagmati River originates from eastern hill, Nagarkot in Kathmandu Valley within the catchment of the Hanumante River. The main steam Bagmati River of the Central Nepal Himalaya is an eighth order perennial river that comprises 39 subbasins of fourth order and higher within catchment of $3761 \mathrm{sq} \mathrm{km}$, and stretches for about $206 \mathrm{~km}$ incising fluvio-lacustrine sedimentary deposits of Kathmandu Valley, Lesser Himalaya, Siwaliks and Indo-Gangetic Plain within the territory of Nepal.
The result of morphological analysis of Bagmati River reveals that meander wavelength, meander belt width and radius of curvature show fluctuating trend of variation from upstream to downstream segments along the main stem river. There seems to be weak relationship between geological terrains and morphological parameters. However, the portion of the seventh order river flowing over the substrate of the fluvio-lacustrine valley-fill sediment in the Kathmandu Valley possesses higher meandering wavelength; and slightly increasing values of radius of curvature can be observed between the terrains of the Mahabharat Range and the Siwalik Range.

The sinuosity of the main stem Bagmati River shows fluctuating trend though it shows overall increase. Out of 43 segments, 29 are determined to be sinuous channels and 13 meandering channels. The eighth order segment is more sinuous than the seventh order segments. This increase in sinuosity is attributed to the decrease in slope and competency of the river as it emerges out from the Mahabharat Range to the SubHimalayan (Siwalik) Range. 
The stream segments of the Bagmati River fall on A-, B-, C-, G- and D-type categories. The segments of the main stem Bagmati River flowing over the substrate of the fluvio-lacustrine valley-fill sediment in the Kathmandu belong to C-type stream. A-type streams are developed at segments which flow through the Tistung Formation and granite terrains of the Lesser Himalaya (Mahabharat Range). Likewise, B- and Gtype streams are developed in terrains of the Lesser Himalaya and the Sub-Himalaya. D-type stream segment is characteristically developed within the terrain of the Sub-Himalaya (Siwaliks).

\section{ACKNOWLEDGEMENTS}

Authors are thankful to S. B. Maharjan and S. D. Shrestha for fruitful discussions and comments, and NAST for providing a grant for $\mathrm{Ph}$. $\mathrm{D}$. of the first author. Authors also thank B. Maharjan and P. Lasiwa for their assistance during field survey.

\section{REFERENCES}

Adhikary T.P. and Rimal, L. N., 1996. Stratigraphy and structural framework of the Sub-Himalaya, Bagmati River region, Central Nepal. Journal of the Nep. Geol. Soc., Vol. 13, pp. 37-50.

Bhusal, J.K., 1998. Sediment transport on major rivers in Nepal, Aspects and impacts of a changing sediment regime. Asian Institute of Technology, Bankok, Thailand, Nov 16-20-1998, pp. 31-38.

DMG, 1998, Engineering and Environmental Geological Map of Kathmandu Valley, Department of Mines and Geology, Lainchaur, Kathmandu.

DWIDP, 2005. The preparation of water-induced hazard maps of the Bagmati River Basin. Department of Water Induced Disaster Prevention (DWIDP)/Silt Consults, ERMC and TECHDA JV. Unpublished report.

DWIDP, 2009. The preparation of flood risk vulnerability map of the Kathmandu Valley. Department of Water Induced Disaster Prevention (DWIDP), Full Bright Consultancy and Geo Consult JV. Unpublished report.

Gautam, P., Rösler, W., 1999. Depositional chronology and fabric of Siwalik group sediments in Central Nepal from magnetostratigraphy and magnetic anisotropy. Journal of Asian Earth Sciences 17, 659-682. http://dx.doi.org/10.1016/S13679120(99)00021-8

Ghimire, S.K., Higaki, D., and Bhattarai, T.P., 2006. Gully erosion in the Siwalik Hills, Nepal: estimation of sediment production from active ephemeral gullies. Earth Surface Processes and Landform, v. 31., pp. 155-165. http://dx.doi.org/10.1002/esp. 1320

Leopold, L.B. and M.G. Wolman, 1957. River channel pattern-braided, meandering and straight, USGS Professional Paper, 282p.

L.B. Leopold, M.G. Wolman and J.P. Miller, 19694. Fluvial processes in Geomorphology, W.H. Freeman, San fransisco.

Muratani, T., Brierley, G.J., Trustrum, N.A. and Page, M., 2001. Source-to-sink sedimentary cascades in Pacific rim geo-system. Matsumoto sabo work office, Ministry of land Infrastructure and transport, Japan.

Rosgen, D.L., 1976. The use of colour infrared photography for source area. In: proceedings of the third inter-agency sediment conference, Water Resources Council, pp. 30-42.

Rosgen, D.L., 1994. A classification of natural rivers, Cantenna, v. 22, pp. 169-199. http://dx.doi.org/10.1016/0341-8162(94)90001-9

Selby, M.J., 1993. Earth's Changing Surface, An Introduction to Geomorphology. 239p.

Shrestha, M.B., Tamrakra, N.K., and Miyazaki, T., 2008. Morphometry and sediment dynamics of the Churia River area, Siwalik Range in Nepal. Boletin de Geologia, v. 30, pp. 35-48.

Shrestha, P. and Tamrakar, N.K., 2007a. Streambank erodibility and lateral instability hazard in the Manahara River, Kathmandu Bsin, Nepal. Journ. Nepal Geol. Soc., v. 35, pp. 55-66.

Shrestha, P. and Tamrakar, N.K., 2007b. Bank erosion and bank material loss potential in Manahara River, Kathmandu, Nepal. Bull. Dept. Geol., Tribhuvan University, Kathmandu, Nepal, v. 10, pp. 33-44.

Stöcklin, J., 1980. Geology of Nepal and its regional frame. Jour. Geol. Soc. London, v. 137, pp. 1-34. http://dx.doi.org/10.1144/gsjgs.137.1.0001

Stöcklin, J. and Bhattarai, K.D., 1977. Geology of Kathmandu area and central Mahabharat Range Nepal. Report of Department of Mines and Geology Kathmandu, Nepal/UNDP, unpublished report, 86p.

Strahler, A.N., 1969. Physical Geography. 3rd edition, John Willey and Sons, Inc. New York.

Tamrakar, N.K. and Shrestha, M.B., 2008. Relationship between fluvial clastic sediment and source rock abundance in Rapti River Basin of Central Nepal Himalaya. Boletin de Geologia, v. 30, no. 1, pp. 63-75.

Yoshida, M. and Igarashi, Y., 1984. Neogene to Quaternary lacustrine sediments in the Kathmandu Valley, Nepal. Journal of Nepal Geological Society, Special Issure, v. 3, pp. 37-100. 